\title{
What do population viability analyses tell about the future for Baltic Dunlin Calidris alpina schinzii and Montagu's Harrier Circus pygargus on Öland?
}

\author{
Vad berättar sårbarhetsanalyser om framtiden för sydlig kärrsnäppa och ängshök \\ på Öland?
}

\author{
PER-ERIC BETZHOLTZ, TOBIAS BERGER, JAN PETERSSON \& JOHAN STEDT
}

\begin{abstract}
Population viability analysis (PVA) has become an important tool in conservation biology. Even though detailed outcomes of PVA:s are constrained by data quality, it is a useful approach when the objective is exploratory, aiming to identify important parameters for viability or to guide future field work on endangered species. In this study we perform PVA:s based on scarce data to explore viability of two endangered bird species, Baltic Dunlin and Montagu's Harrier, on Öland. Our simulation results underline that both species are under severe threats, with a median time to extinction of 24 years in Baltic Dunlin and 63 years in Montagu's Harrier. Sensitivity analyses show that population growth rate is the most important factor for the model outcome in both species. Since there are no apparent threats for adult birds on Öland, this suggests that conservation measures should focus

on improving conditions for successful breeding on the island. In additional simulations we explore some threats in more detail. In the case of Baltic Dunlin nest predation of eggs and chicks increase the extinction risk. In Montagu's Harrier viability increases if breeding attempts within agricultural areas are detected and safeguarded. In order to enhance the PVA model, and build a stage-structured model, we suggest that detailed data on fecundity and survival should be collected.

Per-Eric Betzholtz, Tobias Berger and Johan Stedt, School of Natural Sciences, Linnaeus University, SE-39182 Kalmar, Sweden.

E-mail: per-eric.betzholtz@lnu.se

Jan Petersson, County Administrative Board of Kalmar, SE-39186 Kalmar, Sweden.
\end{abstract}

Received 8 July 2010, Accepted 28 September 2010, Editor: R. Ekblom

\section{Introduction}

Population viability analysis (PVA) is a quantitative method that has become an increasingly important tool in the conservation and management of species (Beissinger \& McCullough 2002, Akçakaya 2004). The reason for this is that the results of a PVA may be used for several objectives: to assess the vulnerability of species to go extinct, to identify which parameters have most effect on viability (i.e. sensitivity analyses) and to evaluate the outcome of a model under different environmental scenarios (Hanski \& Simberloff 1997, Kindvall 1998, Akçakaya \& Sjögren-Gulve 2000, Morris et al. 2002).

PVA:s have received some criticism for producing unreliable estimates when absolute extinction risks on longer terms are simulated (Ludwig 1998, Fieberg \& Ellner 2000), because demographic data from a PVA commonly are uncertain (Caughley 1994). The outcomes of PVA:s have been validated by Brook et al. (2000), who showed that predic- tions of abundance and risk of decline closely matched observed outcomes. Data uncertainties can also be handled by performing sensitivity analyses to identify important assumptions and parameters of a PVA (Akçakaya \& Sjögren-Gulve 2000). Furthermore, when data are scarce and only based on surveys of population numbers from short-time series, it is still often a useful approach to perform a PVA. This is especially true when the objective of a PVA is exploratory, to identify important parameters of viability or to guide further field work (Dunham et al. 2006).

In this study we use PVA to explore viability under different scenarios in two endangered Swedish bird species on Öland, the Baltic Dunlin Calidris alpina schinzii and the Montagu's Harrier Circus pygargus. Both species have their main Swedish distribution on Öland. We use scalar models based on short time series of surveys in population numbers, and incorporate data uncertainties in our simulations by performing different sets of sensitivity analyses. We discuss conservation implications 
of our simulation outcomes, and how our results may guide future field work of the two species on Öland.

\section{Materials and methods}

\section{Study area}

The island of Öland is situated in the Baltic Sea, close to the Swedish mainland. It is $130 \mathrm{~km}$ long and between 10 and $20 \mathrm{~km}$ wide, built up on a limestone plateau. Öland is dominated by an agricultural landscape, but there are also other habitats such as coastal meadows, wetland areas, alvar land, large and continuous areas of deciduous forest and in the northern parts also pine forest. At least 150 bird species breed here regularly (Länsstyrelsen Kalmar 1999), and several of these species are included in the Swedish red-list (Gärdenfors 2010).

\section{Study species}

The Baltic Dunlin has its main breeding grounds on Iceland and in Great Britain, but there are also small populations in southern Scandinavia and on Greenland (Thorup 2006). The Baltic Dunlin has specific habitat requirements and prefers coastal wetlands (preferably grazed by cattle) with vegetation not more than $10-20 \mathrm{~cm}$ high. It also prefers a mosaic structure of varying vegetation heights and access to nearby muddy beaches for foraging (Blomqvist 1994, Jönsson 2006). The Swedish population, estimated at 120 pairs, has shown a long-lasting decrease with a decline of $70 \%$ during the last twenty years (Gärdenfors 2010). Öland hosts the most important breeding grounds for the Baltic Dunlin in Sweden and currently 60-70 pairs breed here (Flodin et al. 2010). The species has declined severely also on Öland, during the 1980s and 1990s more than 100 pairs were breeding here.

The reasons for the Swedish population decline are not fully known, but several explanations have been put forward. One important factor is habitat loss because of ceased grazing followed by a closure of suitable habitats. Other causes that have been suggested are habitat deterioration from drainage of the coastal meadows, and nest predation of eggs and chicks (Ottvall 2005, Jönsson 2006, Flodin et al. 2010). A high nest predation has been observed, as much as $70 \%$ of the nests have been predated on Öland during some years (Ottvall 2005, Ottvall \& Larsson 2005). A low genetic variation has also affected viability in fragmented Baltic Dunlin populations in western Sweden (Ottvall \& Larsson 2005, Blomqvist \& Pauliny 2007).
Since the Baltic Dunlin shows a high level of site fidelity (Jönsson 1991), Flodin et al. (2010) suggest that low genetic variation may also be a severe factor behind the decline.

The Baltic Dunlin is red-listed as critically endangered (CR) in Sweden (Gärdenfors 2010), and an action plan for the conservation of the species has been established. Primary goals are to stop the decline of the population and explore the genetic status of all Swedish subpopulations (Flodin et al. 2010), and they suggest that the first goal can be achieved if each breeding pair produces at least two hatched chicks per year.

The Montagu's Harrier has a fragmented distribution in Eurasia, with the vast majority of breeding pairs in France, Spain, Portugal, Ukraine, Belarus and the Baltic States (Birdlife International 2004). It occurs in a wide range of open habitats such as grasslands, arable land and wetlands (Arroyo et al. 2002). In Sweden the species has a relatively short history as a permanent breeder. During the 1930s and 1940s a few pairs were breeding in Scania, but this population subsequently became extinct due to persecution and collecting of eggs (Rodebrand 2009). During the 1940s the species colonized Öland, and in the following decades a stable population was built up on the island, reaching 40-45 pairs during the 1970s and 1980s (Rodebrand 2009). Öland is the Swedish stronghold of the species and currently holds $30-35$ of the estimated Swedish population of 55 pairs (Gärdenfors 2010). On Öland the species utilizes three different kinds of habitats, Cladium mariscus marshes, $D a$ siphora fruticosa areas on alvar land and agricultural fields.

The Swedish population of Montagu's Harrier has decreased by $20 \%$ during the last twenty years (Gärdenfors 2010). Important reasons behind the decline are deterioration of breeding habitats, competition with Marsh Harriers Circus aeruginosus and predation from Goshawks Accipiter gentilis (Rodebrand 2009, Gärdenfors 2010). Furthermore, Rodebrand (2009) suggests that another factor behind the decline is that several pairs are breeding in suboptimal habitats, i.e. in agricultural fields, where the breeding success is lower. This is because the fields are often harvested before the young have fledged, and heavy rains bend down the straw of the crop to the ground, exposing the nest to predators (Rodebrand 2009).

The Montagu's Harrier is red-listed as endangered (EN) in Sweden (Gärdenfors 2010), and an action plan for the conservation of the species has been established (Rodebrand 2009). The aims of 
the action plan are to stop the decreasing trend of the Swedish population, and to establish a viable population on Öland. This goal should be fulfilled if each breeding pair produces at least two fledglings per year.

\section{Model overview and parameterization}

We used the generic software RAMAS GIS 3.0 (Akçakaya 1998) to parameterize our models. We built scalar models from time-series data of population numbers, without age or stage structure. The scalar model used by RAMAS is created from the equation $\mathrm{N}_{t+1}=\lambda_{t} \mathrm{~N}_{t}$, where $\lambda_{t}$ is a deviate taken from the lognormal distribution with a mean and standard deviation estimated for the time series in question. The standard deviation includes all environmental variability, and will be referred to as environmental stochasticity. We calculated the realized rate of population change between successive surveys in a continuous series as $\lambda_{i}=\left(N_{i} / N_{i-1}\right)$, where $N_{i}$ is the population size at year $i,(i=0,1$, $2 \ldots q)$. All survey data had annual time steps. These population growth rates were then used to calculate the mean and standard deviation of $\lambda$ for the model created in the software module RAMAS metapop. As the initial population size, we used the population number of the last year in the time-series. We incorporated density dependence as a ceiling-type density, i.e. the population growth is exponential until it reaches the ceiling-value used as carrying capacity. Differences in individual survival and fecundity may have a significant effect on population growth, especially in small populations (Soulé 1986, Lande 1988). Therefore we also included demographic stochasticity in our simulations, which in RAMAS is incorporated by sampling the number of individuals from binomial distributions. We ran the model for a time frame of 100 years, with 10,000 replicates. As a measure of viability, we used the extinction risk for the time frame of 100 years, and the median time to extinction. In species with overlapping generations, as in this case, generations could be used instead of years as the time frame. Since there is no data on survival for the studied species on Öland, and the aim was exploratory, we used years as the time frame. To indicate this population growth rate is denoted by $\lambda$, instead of the generally used $\mathrm{R}$. To explore the degree to which each parameter affects the model outcome, we performed sensitivity analyses of model parameters and compared them to a status quo scenario (no change scenario). We included the parameters population growth rate $\left(\lambda_{t}\right)$, environ-
Table 1. Number of pairs of Baltic Dunlin on Öland based on full scale surveys performed in 1988, 1998 and 2008, and from surveys 2003-2008 where 20\% of the suitable breeding habitat was sampled each year. Antal par av sydlig kärrsnäppa på Öland baserat på heltäckande inventeringar 1988, 1998 och 2008, samt inventeringar 2003-2008 där 20\% av lämplig häckningsmiljö inventerades (stickprovsinventering).

\begin{tabular}{ccc}
\hline & $\begin{array}{c}\text { Sample survey } \\
\text { Stickprovsinv. }\end{array}$ & $\begin{array}{c}\text { Full scale survey } \\
\text { Heltäckande inv. }\end{array}$ \\
\hline 1988 & - & 132 \\
1998 & - & 105 \\
2003 & 27 & - \\
2004 & 30 & - \\
2005 & 19 & - \\
2006 & 20 & - \\
2007 & 13 & - \\
2008 & 15 & 62 \\
\hline
\end{tabular}

Table 2. Number of pairs of Montagu's Harrier on Öland 2004-2008, including number of pairs in the three main habitats; Cladium mariscus marsh (denoted $\mathrm{Cm}$ ), Dasiphora fruticosa area on alvar land (denoted $D f$ ) and agricultural fields (denoted Af). Antal par av ängshök på Öland 2004-2008, fördelat på de tre häckningsmiljöerna; våtmarker med ag (förkortat $\mathrm{Cm}$ ), alvarmark med ölandstok (förkortat Df) och odlingsmark (förkortat Af).

\begin{tabular}{rrrrr}
\hline & Total & $C m$ & Df & Af \\
\hline 2004 & 31 & 13 & 14 & 4 \\
2005 & 23 & 9 & 11 & 3 \\
2006 & 29 & 11 & 14 & 4 \\
2007 & 36 & 15 & 8 & 13 \\
2008 & 33 & 12 & 16 & 5 \\
\hline
\end{tabular}

mental stochasticity $\left(\operatorname{std}_{\lambda t}\right)$, initial abundance and carrying capacity (i.e. the ceiling value used). We ran the sensitivity analyses with an increase and a decrease of $10 \%$ and $20 \%$ on the value of each parameter.

Full scale surveys of breeding Baltic Dunlin have been performed on Öland 1988 (Pettersson et al. 1995), 1998 (Pettersson 2001) and 2008 (Svensk Naturförvaltning 2009). There have also been annual surveys carried out on $20 \%$ of the area of coastal wetlands on Öland, running between 2003 and 2008 (Table 1). The full scale survey of 2008 resulted in 62 breeding pairs. We parameterized the model from the time-series 2003-2008 $(\lambda=0.920$, $\operatorname{std}_{\lambda}=0.257$ ), but used the value from the full scale survey in 2008 as the initial population size in 
our simulations. Since there is no lack of suitable breeding habitats carrying capacity was set to 250 pairs, twice the maximum number of breeding pairs in recent decades. Montagu's harrier has been surveyed in detail on Öland under two different time periods, 1975-1981 and 2004-2008 (Länsstyrelsen i Kalmar in letter). We used the latter time-series (Table 2) for the parameterization of the model $(\lambda=$ $\left.1.040, \operatorname{std}_{\lambda}=0.254\right)$. Carrying capacity was set to 55 pairs, slightly higher than the maximum number of breeding pairs in recent decades.

Besides performing the status quo scenario simulations described above, data allowed us to explore some of the threats indicated in the action plans (Rodebrand 2009, Flodin et al. 2010). In the case of Baltic Dunlin we performed additional simulations on nest predation, since this factor is suggested as a threat for population decline on Öland, and also varies highly between years (Ottvall 2005, Ottvall \& Larsson 2005). Since our status quo simulation is based on a short time-series survey, covering $20 \%$ of suitable breeding habitats, there is a risk that we did not catch the effects of nest predation fully in our simulation model. In RAMAS, nest predation is incorporated in the model as a catastrophic event. The model is parameterized with a probability for nest predation to occur, and how severe the effect is when it happens. We explored two different levels of nest predation in our simulations, $20 \%$ and $50 \%$. In addition, we included that $50 \%$ of the eggs/chicks from a breeding pair were predated when a nest was attacked. This is because mammals regularly predate all four eggs

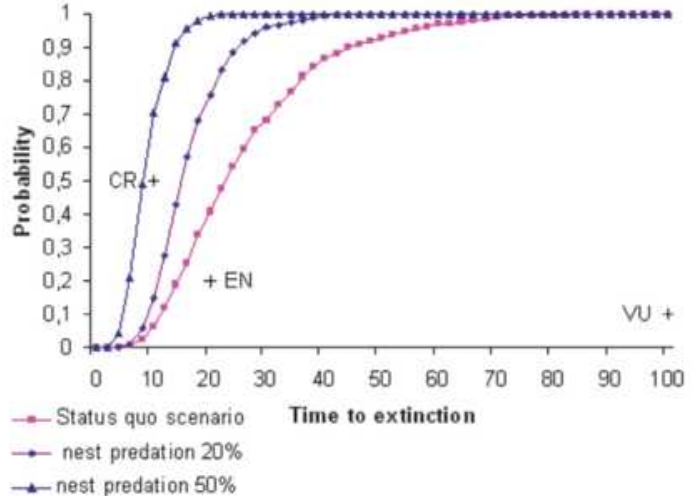

Figure 1. Cumulative extinction risk the next 100 years in Baltic Dunlin on Öland. Three different scenarios are indicated; a status quo scenario (no change), a scenario with $20 \%$ nest predation and a scenario with $50 \%$ nest predation (details in text). The red-list categories Critically endangered $(\mathrm{CR})$, Endangered (EN) and Vulnerable (VU) are denoted in the figure.

Kumulativ utdöenderisk de närmaste 100 åren hos sydlig kärrsnäppa på Öland. Tre olika scenarior visas; ett scenario med oförändrade parametervärden och två scenarior där bopredation inkluderas och uppgår till 20 respektive 50\% årligen (detaljer $i$ texten). Gränserna för rödlistekategorierna akut hotad (CR), hotad (EN) och sårbar (VU) anges i figuren.

in the nest, while birds such as Corvidae often destroy only one or two of the eggs (G. Norevik, pers. comm.). In Montagu's Harrier we performed additional simulations to explore if different population growths among the three main habitats on Öland

Table 3. Viability estimates from sensitivity analysis in Baltic Dunlin on Öland, based on survey data from 2003-2008. A status quo scenario (denoted in bold) and scenarios where the model parameters are changed by $\pm 10 \%$ and $\pm 20 \%$ respectively, are presented as extinction probabilities in the next 100 years (Ext. prob.) and median time to extinction in years (Md ext.). Model parameters are denoted as follows; Population growth rate (Pop. growth), Environmental stochasticity (Env. stoch.), Initial abundance (Init. abun.) and Ceiling value of population size (Ceil. val.).

Utdöenderisker från känslighetsanalyser av sydlig kärrsnäppa på Öland, baserade på inventeringsdata 2003 2008. Ett scenario med oförändrade parametervärden (i fetstil) jämförs med scenarior där modellparametrarna ändras med $\pm 10 \%$ och $\pm 20 \%$, och presenteras som utdöenderisker inom de närmaste 100 åren (Ext. prob.) och mediantid till utdöende $i$ antal år (Md ext.). Modellparametrarna förkortas enligt följande; populationstillväxt (pop. growth), omgivningsstokasticitet (env. stoch.), initial populationsstorklek (init. abun.) och högsta populationsstorlek (ceil. val.).

\begin{tabular}{ccccccccc}
\hline $\begin{array}{c}\% \\
\text { change }\end{array}$ & \multicolumn{2}{c}{ Pop. growth } & \multicolumn{2}{c}{ Env. stoch. } & \multicolumn{2}{c}{ Init. abun. } & \multicolumn{2}{c}{ Ceil. val. } \\
\hline-20 & 1.00 & 11 & 1.00 & 22 & 1.00 & 23 & 1.00 & 23 \\
-10 & 1.00 & 14 & 1.00 & 23 & 1.00 & 23 & 1.00 & 24 \\
$\mathbf{0}$ & $\mathbf{1 . 0 0}$ & $\mathbf{2 4}$ & $\mathbf{1 . 0 0}$ & $\mathbf{2 4}$ & $\mathbf{1 . 0 0}$ & $\mathbf{2 4}$ & $\mathbf{1 . 0 0}$ & $\mathbf{2 4}$ \\
+10 & 0.65 & 67 & 1.00 & 25 & 1.00 & 24 & 1.00 & 25 \\
+20 & 0.02 & $>100$ & 1.00 & 26 & 1.00 & 24 & 1.00 & 25 \\
\hline
\end{tabular}


affected viability, compared to the status quo scenario described above. Since the survey of 2004 2008 also included categorization of habitats, we used this dataset also in these simulations (Table 2; Cladium mariscus marshes: $\lambda=1.086, \mathrm{std}_{\lambda}=0.289$; Dasiphora fruticosa areas on alvar land: $\lambda=1.032$, $\operatorname{std}_{\lambda}=0.428$; agricultural fields: $\lambda=1.429, \operatorname{std}_{\lambda}=$ $1.275)$. We were also able to correlate the number of breeding pairs among habitats, and include these correlations in the simulations. Since Rodebrand (2009) suggested that a possible threat is due to more pairs breeding in suboptimal habitats, i.e. in agricultural fields, we also explored how dispersal to agricultural fields from the two other habitats affected the model outcome. In RAMAS dispersal is handled as proportions of the population. We used $10 \%$ and $30 \%$ of the populations in the two other habitats dispersing to agricultural fields each year.

\section{Results}

\section{Baltic Dunlin}

The extinction risk in the next 100 years was estimated at $100 \%$, with a median time to extinction of 24 years (Figure 1, Table 3). Sensitivity analyses showed that population growth rate was the single most important parameter for the model outcome, while the parameters environmental stochasticity, initial population size and carrying capacity did not change the model outcome (Table 3). According to the quantitative E-criteria of the red-list, the simulation outcome for the status quo scenario of Baltic Dunlin on Öland corresponds to the threat category endangered (EN) (c.f. Figure 1), indicating that the extinction risk is higher than $20 \%$ in the next 20 years.

When nest predation was included as a separate factor in the simulations, viability of the Baltic Dunlin decreased. When probability of nest predation to occur was set to $20 \%$ and $50 \%$, median time to extinction decreased from 24 years in the status quo scenario to 15 and 8 years, respectively.

\section{Montagu's Harrier}

The extinction risk in the next 100 years was estimated at $70 \%$, with a median time to extinction of 63 years (Figure 2, Table 4). Sensitivity analyses showed that population growth rate was the single most important parameter for the model outcome. The environmental stochasticity also affected the outcome to a certain degree, while initial abundance and carrying capacity only affected the outcome of the model marginally (Table 4). Accord-

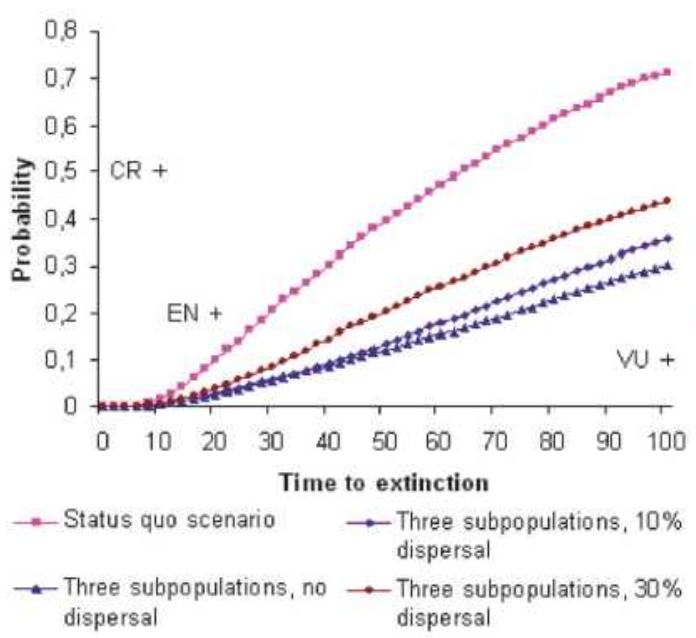

Figure 2. Cumulative extinction risk the next 100 years in Montagu's Harrier on Öland. Four different scenarios are indicated: a status quo scenario (no change), a scenario with populations in the three main breeding habitats and two scenarios with dispersal to the suboptimal breeding habitat agricultural fields from the two other habitats by a proportion of $10 \%$ and $30 \%$ dispersal each year (details in text). The redlist categories Critically endangered (CR), Endangered (EN) and Vulnerable (VU) are denoted in the figure.

Kumulativ utdöenderisk de närmaste 100 åren hos ängshök på Öland. Fyra olika scenarior visas; ett scenario med oförändrade parametervärden och tre scenarior där bestånden $i$ de tre häckningsmiljöerna betraktas separat, dels utan spridning mellan häckningsmiljöerna och dels med spridning till odlingsmark från de andra två häckningsmiljöerna med en omfattning av 20 respektive $50 \%$ årligen. Gränserna för rödlistekategorierna akut hotad (CR), hotad (EN) och sårbar $(V U)$ anges i figuren.

ing to the quantitative E-criteria of the red-list the simulation outcome for the status quo scenario of Montagu's Harrier on Öland corresponds to the threat category vulnerable (VU) (c.f. Figure 2), indicating that the extinction risk is higher than $10 \%$ in the next 100 years.

The simulations where the population on Öland were treated as three subpopulations in the main habitats increased the viability. The extinction risk in the next 100 years was $30 \%$ and the median time to extinction $>100$ years (Figure 2, Table 5). The sensitivity analyses revealed the same pattern as in the simulations with the status quo scenario (Table 5). When we included dispersal to the suboptimal habitat agricultural fields, the extinction risk was $35 \%$ and $43 \%$ in the next 100 years for a $10 \%$ and $30 \%$ proportion of dispersal, respectively. The me- 
Table 4. Viability estimates from sensitivity analysis in Montagu's Harrier on Öland, based on survey data from 2004-2008. A status quo scenario (denoted in bold) and scenarios where the model parameters are changed by \pm 10 and $\pm 20 \%$ respectively, are presented as extinction probabilities in the next 100 years (Ext. prob.) and median time to extinction in years (Md ext.). Model parameters are denoted as follows; Population growth rate (Pop. growth), Environmental stochasticity (Env. stoch.), Initial abundance (Init. abun.) and Ceiling value of population size (Ceil. val.).

Utdöenderisker från känslighetsanalyser av ängshök på Öland, baserade på inventeringsdata 2004-2008. Ett scenario med oförändrade parametervärden ( $i$ fetstil) jämförs med scenarior där modellparametrarna ändras med \pm 10 och $\pm 20 \%$, och presenteras som utdöenderisker inom de närmaste 100 åren (Ext. prob.) och mediantid till utdöende i antal år (Md ext.). Modellparametrarna förkortas enligt följande; populationstillväxt (Pop. growth), omgivningsstokasticitet (Env. stoch.), initial populationsstorklek (Init. abun.) och högsta populationsstorlek (Ceil. val.).

\begin{tabular}{ccccccccc}
\hline $\begin{array}{c}\text { \% } \\
\text { change }\end{array}$ & \multicolumn{2}{c}{ Pop. growth } & \multicolumn{2}{c}{ Env. stoch. } & \multicolumn{2}{c}{ Init. abun. } & \multicolumn{2}{c}{ Ceil. val. } \\
\hline-20 & 1.00 & 12 & 0.55 & 88 & 0.73 & 57 & 0.76 & 56 \\
-10 & 0.99 & 21 & 0.63 & 74 & 0.70 & 62 & 0.74 & 59 \\
$\mathbf{0}$ & $\mathbf{0 . 7 1}$ & $\mathbf{6 3}$ & $\mathbf{0 . 7 1}$ & $\mathbf{6 2}$ & $\mathbf{0 . 7 1}$ & $\mathbf{6 2}$ & $\mathbf{0 . 7 1}$ & $\mathbf{6 3}$ \\
+10 & 0.05 & $>100$ & 0.76 & 54 & 0.70 & 64 & 0.68 & 66 \\
+20 & 0.01 & $>100$ & 0.83 & 47 & 0.70 & 65 & 0.66 & 69 \\
\hline
\end{tabular}

Table 5. Viability estimates from sensitivity analysis in Montagu's Harrier on Öland with populations in the three main habitats on Öland (c.f. Table 2). No dispersal among populations is included. A status quo scenario (denoted in bold) and scenarios where the model parameters are changed by \pm 10 and $\pm 20 \%$ respectively, are presented as extinction probabilities in the next 100 years (Ext. prob.) and median time to extinction in years (Md ext.). Model parameters are denoted as follows; Population growth rate (Pop. growth), Environmental stochasticity (Env. stoch.), Initial abundance (Init. abun.) and Ceiling value of population size (Ceil. val.). Utdöenderisker från känslighetsanalyser av ängshök på Öland med antalet par i de tre huvudsakliga biotoperna betraktade som delpopulationer (jmf. Tabell 2). Ingen spridning mellan delpopulationerna är inkluderad. Ett scenario med oförändrade parametervärden ( $i$ fetstil) jämförs med scenarior där modellparametrarna ändras med \pm 10 och $\pm 20 \%$, och presenteras som utdöenderisker inom de närmaste 100 åren (Ext. prob.) och mediantid till utdöende $i$ antal år (Md ext.). Modellparametrarna förkortas enligt följande; populationstillväxt (Pop. growth), omgivningsstokasticitet (Env. stoch.), initial populationsstorklek (Init. abun.) och högsta populationsstorlek (Ceil. val.).

\begin{tabular}{ccccccccc}
\hline $\begin{array}{c}\% \\
\text { \% }\end{array}$ & \multicolumn{2}{c}{ Pop. growth } & \multicolumn{2}{c}{ Env. stoch. } & \multicolumn{2}{c}{ Init. abun. } & \multicolumn{2}{c}{ Ceil. val. } \\
change & Ext. prob & Md ext. & Ext. prob. & Md ext. & Ext. prob. & Md ext. & Ext. prob. & Md ext. \\
\hline-20 & 1.00 & 12 & 0.15 & $>100$ & 0.35 & $>100$ & 0.40 & $>100$ \\
-10 & 0.98 & 31 & 0.20 & $>100$ & 0.33 & $>100$ & 0.35 & $>100$ \\
$\mathbf{0}$ & $\mathbf{0 . 3 1}$ & $>\mathbf{1 0 0}$ & $\mathbf{0 . 3 1}$ & $>\mathbf{1 0 0}$ & $\mathbf{0 . 3 1}$ & $>\mathbf{1 0 0}$ & $\mathbf{0 . 3 1}$ & $>\mathbf{1 0 0}$ \\
+10 & 0 & $>100$ & 0.41 & $>100$ & 0.28 & $>100$ & 0.26 & $>100$ \\
+20 & 0 & $>100$ & 0.52 & 97 & 0.27 & $>100$ & 0.25 & $>100$ \\
\hline
\end{tabular}

dian time to extinction was $>100$ years in both scenarios (Figure 2, Table 5).

\section{Discussion}

Our simulation results underline that the two species suffer a high risk of extinction in the close future. Sensitivity analyses indicated population growth rate as the most important single factor for viability in both species. This finding agrees with the general aims of the action plan for Montagu's
Harrier (Rodebrand 2009) and Baltic Dunlin (Flodin et al. 2010); the decline of both species will be stopped if the fecundity is high enough. However, in our simulation model the factor population growth rate includes fecundity, juvenile and adult survival. We had no opportunity to indicate which of those measures that is most important for viability on Öland, since there is no data available. Several studies in waders closely related to the Baltic Dunlin, i.e. other Calidris species, have indicated adult survival as most important for the population 
growth rate (e.g. Hitchcock \& Gratto-Trevor 1997, Koivula et al. 2008). There are no apparent threats for adult birds on Öland. Therefore, what can be done locally on Öland is to enhance possibilities for successful breeding. Several conservation measures are discussed in the two action plans for achieving this goal.

In the case of Baltic Dunlin habitat deterioration has been suggested as one important factor behind the population decline, i.e. from ceased grazing followed by a closure of suitable coastal meadows. However, on Öland the area of coastal meadows suitable for breeding has not declined during the last twenty years. Therefore factors associated with habitat quality are probably involved. Our simulations showed that nest predation increases the extinction risk (Figure 1). Observe that the extinction risk is high even without nest predation, but that nest predation further increases the threats. Nest predation on waders mainly occurs during night, indicating that mammals are involved (Ottvall 2009, Ottvall \& Johansson 2009).

In the case of Montagu's Harrier our simulation results showed that populations in three different main habitats on Öland are more viable in the long run than a single population using only one habitat type (Figure 2). This is because the overall extinction risk will be reduced since all habitat types are not affected to the same degree from extreme weather events or predation pressure (c.f. Gilpin \& Hanski 1991). Further our simulations showed that dispersal to agricultural fields, from the other two habitats, increased viability even though the breeding success is lower in this habitat. This opens up a new perspective. Since there is a marked dispersal to agricultural fields during certain years, e.g. in 2007 (Table 2), specific measures of detecting and safeguarding the nests during these years could substantially enhance the number of successful broods on Öland. We argue that in order to fulfil the goal in the action plan, 45 breeding pairs of Montagu's Harrier on Öland, a specific management of breeding in agricultural fields will be a key factor. Two possibilities that have been tested in Sweden are to protect large enough areas, at least $25 \times 25 \mathrm{~m}$, around the nest when crops in agricultural fields are harvested, and to plan the timing of harvest activities in relation to status of breeding (Rodebrand 2009). In Western Europe conservation measures in agricultural areas, together with dispersal between populations, are key factors for the survival of the species (Arroyo et al. 2002). There is no evidence of a population decline of Montagu's Harrier in neighbouring countries (Rodebrand 2009). This suggests that immigration from those areas is a factor that may also enhance viability for the population on Öland.

The viability outcomes in our models predicted different threat categories for the studied species compared to the Swedish red-list (Gärdenfors 2010). However, the quantitative E-criteria (i.e. performing a PVA) is just one of five sets of criteria used for classification of threat categories. The other criteria (A-D) are built on measures such as distribution area, population size, number of reproducing individuals, rate of decline etc. If the threat categories differ among criteria, species are redlisted according to the most severe threat category. Both Baltic Dunlin and Montagu's Harrier are classified according to an ongoing decline and a low number of reproducing individuals, not according to a PVA. Therefore our simulations may indicate another threat category than the current red-list classification. A complete overview of the red-list criteria is found on the webpage of the Swedish Species Information Centre (www.artdata.slu.se/ rodlista/).

\section{Improving the PVA model}

The outcome of a PVA has a higher accuracy if demographic data as fecundity and survival, or surveys on population numbers, are collected over many years. One reason is that the chance of including years with extreme weather situations increases. When there are data on fecundity and survival also more realistic models may be built, i.e. stage-structured models. Scalar models sometimes overestimate extinction risks, compared to structured models including demographic data on fecundity and survival (Dunham et al. 2006). Therefore we suggest that studies on fecundity and survival of Baltic Dunlin and Montagu's Harrier populations on Öland should be performed. Data from such studies would definitely enhance the PVA models and the reliability of the model outcomes. Additional support for this view also comes from the sensitivity analyses, indicating population growth rate as the single most important factor for viability in both species.

\section{Acknowledgements}

We thank Staffan Rodebrand for helpful comments on Montagu's Harrier, County Administrative Board of Kalmar for access to unpublished data, Rowena Jansson for valuable language editing, Jonas Waldenström and two anonymous reviewers 
for suggesting several valuable improvements on the manuscript.

\section{References}

Akçakaya, H.R. 1998. RAMAS GIS: Linking landscape data with population Viability Analysis (version 3.0). Applied Biomathematics, Setauket, New York.

Akçakaya, H.R. 2004. Using models for species conservation and management: an introduction. Pp. 3-14 in Species conservation and management (Akçakaya et al. eds), Oxford University Press, New York.

Akçakaya, H.R. \& Sjögren-Gulve, P. 2000. Population viability analysis in conservation planning: an overview. Ecological bulletins 48: 9-21.

Arroyo, B., Garcia, J.T. \& Bretagnolle, V. 2002. Conservation of Montagu's harrier (Circus pygargus) in agricultural areas. Animal Conservation 5: 283-290.

Beissinger, S.R. \& McCullough, D.R. (eds). 2002. Population Viability Analysis. University of Chicago Press, Chicago.

Birdlife International. 2004. Threatened birds of the world 2004. CD-rom.

Blomqvist, D. 1994. Den sydliga kärrsnäppan - förekomst, häckningsbiologi och flyttning. Calidris 23: 81-85 [in Swedish].

Blomqvist, D. \& Pauliny, A. 2007. Inavel och förlust av genetisk variation hos sydlig kärrsnäppa (Calidris alpina schinzii) på svenska Västkusten. Länsstyrelsen i Halland, Meddelande 2007:17 [in Swedish].

Brook, B.W., O'Grady, J.J., Chapman, A.P., Burgman, M.A., Akçakaya, H.R. \& Frankham, R. 2000. Predictive accuracy of population viability analysis in conservation biology. Nature 404: 385-387.

Caughley, G. 1994. Directions in conservation biology. Journal of Animal Ecology 63: 215-244.

Dunham, A.E., Akçakaya, H.R. \& Bridges, T.S. 2006. Using scalar models for precautionary assessments of threatened species. Conservation Biology 20: 1499-1506.

Fieberg, J. \& Ellner, S.P. 2000. When is it meaningful to estimate an extinction probability? Ecology 81: 2040-2047.

Flodin, L.-Å., Larsson, M. \& Ottvall, R. 2010. Atgärdsprogram för bevarande av sydlig kärrsnäppa. Naturvårdsverket, Stockholm [in Swedish].

Gilpin, M.E. \& Hanski, I. 1991. Metapopulation dynamics. Academic press, London.

Gärdenfors, U. 2010. The 2010 redlist of Swedish species. Swedish Species Information Centre, Uppsala.

Hanski, I. \& Simberloff, D. 1997. The metapopulation approach, its history, conceptual domain, and application to conservation. Pp. 5-26 in Metapopulation biology: Ecology, genetics, and evolution (Hanski, I. \& Gilpin, M.E. eds), Academic Press, San Diego.

Hitchcock, C.L. \& Gratto-Trevor, C. 1997. Diagnosing a shorebird local population decline with a stage-structured population model. Ecology 78: 522-534.

Jönsson, P.E. 1991. Reproduction and survival in a declining population of the Southern Dunlin Calidris alpina schinzii. Wader Study Group Bulletin 61: 56-68.

Jönsson, P.E. 2006. Artfaktablad - Calidris alpina schinzii - sydlig kärrsnäppa. ArtDatabanken, SLU, Uppsala [in Swedish].
Kindvall, O. 1998. Introduktion till sårbarhetsanalyser. ArtDatabanken Rapporterar 2. Artdatabanken, SLU, Uppsala [in Swedish].

Koivula, K., Pakanen, V.-M., Rönkä, A. \& Belda, E.-J. 2008. Steep past and future population decline in an arctic wader: dynamics and viability of Baltic Temminck's stints Calidris temminckii. Journal of Avian Biology 39: 329-340.

Lande, R. 1988. Genetics and demography in biological conservation. Science 241: 1455-1460.

Ludwig, D. 1998. Is it meaningful to estimate probability of extinction? Ecology 80: 298-310.

Länsstyrelsen Kalmar. 1999. World heritage convention Swedish nomination. Södra Ölands Odlingslandskap. Länsstyrelsen i Kalmar län.

Morris, W.F., Bloch, P.L., Hudgens, B.R., Moyle, L.C. \& Stinchcombe, J.R. 2002. Population Viability Analysis in endangered species recovery plans: use and future improvements. Ecological applications 12: 708-712.

Ottvall, R. 2005. Boöverlevnad hos strandängshäckande vadare: den relativa betydelsen av predation och trampskador av betesdjur. Ornis Svecica 15: 89-96 [in Swedish].

Ottvall, R \& Larsson, K. 2005. Uppföljning av häckfåglars förekomst och utbredning på Öländska sjömarker. Länsstyrelsen Kalmar län, Meddelande 2005:21 [in Swedish].

Ottvall, R. 2009. Kan predatorkonroll vara ett verktyg för naturvården på öländska sjömarker? Länsstyrelsen Kalmar län, Meddelande 2009:11 [in Swedish].

Ottvall, R. \& Johansson, M. 2009. Försöksstudie på strandängar på södra Öland med riktad jakt på predatorer. Calidris 38: 16-22 [in Swedish].

Pettersson, J., Hellström, M. \& Jonzen, N. 1995. Fåglar på Ölands strandängar. Rapport från Ottenby fågelstation nr. 11 [in Swedish].

Pettersson, J. 2001. Fåglar på Ölands sjömark 1988 och 1998. Länsstyrelsen Kalmar län, Meddelande 2001:12 [in Swedish].

Rodebrand, S. 2009. Atgärdsprogram för ängshök. Naturvårdsverket, Stockholm [in Swedish].

Soulé, M. (ed) 1986. Conservation biology. The science of scarcity and diversity. Sinauer, Sunderland.

Svensk Naturförvaltning. 2009. Fågelfaunan på Ölands sjömarker - inventeringar 1988-2008. Länsstyrelsen i Kalmar län, Meddelande 2009:08 [in Swedish].

Thorup, O. (ed) 2006. Breeding waders in Europe 2000. International wader studies 14. International Wader Study Group.

\section{Sammanfattning}

Sårbarhetsanalys är ett viktigt verktyg för att förutsäga livskraften hos populationer. Metoden bygger på matematiska modeller där man utifrån befintliga uppgifter om arten, t.ex. populationsstorlek och antal häckningar, simulerar populationens framtida dynamik. Resultaten av en sårbarhetsanalys uttrycks ofta som en sannolikhet för utdöende inom en given tidsperiod. Metodens träffsäkerhet begränsas av kvaliteten på demografiska data, t.ex. häckningsframgång och överlevnad. I de fall simuleringarna 
främst syftar till att jämföra olika situationer eller bevarandeåtgärder, och inte till att göra mer exakta förutsägelser, ger metoden en god vägledning även om man har en begränsad mängd data.

I denna studie använder vi sårbarhetsanalys för att undersöka livskraften hos de öländska populationerna av sydlig kärrsnäppa och ängshök, två arter som är hotade och har minskat betydande i populationsstorlek under de senaste decennierna.

\section{Sydlig kärrsnäppa och ängshök}

Den sydliga kärrsnäppan har specifika krav på sin häckningsmiljö och föredrar strandängar med varierande vegetationshöjd som inte överstiger 10-20 $\mathrm{cm}$, och som gärna betas. Det svenska beståndet är uppskattat till 120 par, varav 60 par finns på Öland. Beståndet i Sverige har minskat med 70\% under de två senaste decennierna. En orsak till tillbakagången som framförts är habitatförlust genom upphörande bete, varvid lämplig häckningsmiljö växer igen. Andra orsaker kan vara att strandängarna generellt blivit torrare och att bopredation på ägg och ungar från fåglar och däggdjur ökat. I västra Sverige har även beståndet påverkats negativt av låg genetisk variation. Den sydliga kärrsnäppan är i Sverige rödlistad som akut hotad (CR), vilket innebär att den löper extremt stor risk att dö ut, och ett åtgärdsprogram har därför upprättats.

Ängshöken har en relativt kort historia som häckfågel i Sverige. Under 1930- och 1940-talen fanns några få par i Skåne, men de försvann p.g.a. förföljelse och äggsamlande. Under 1940-talet koloniserades Öland, och beståndet ökade långsamt till 40-45 par under 1970- och 1980-talen. Det svenska beståndet har minskat med $20 \%$ de senaste 20 åren, och för närvarande uppskattas beståndet till ca 55 par varav 30-35 par finns på Öland. På Öland nyttjar arten tre huvudsakliga häckningsmiljöer; våtmarker med ag, alvarmark med ölandstok samt odlingsmark. Flera orsaker till beståndets tillbakagång har framförts såsom försämring av häckningsmiljöernas kvalitet, ökad konkurrens från brun kärrhök och predation på yngre kärrhökar av duvhök. Möjligen påverkas beståndet också negativt av ett ökat antal häckningar i odlingsmarker, där häckningsframgången är sämre. Arten är i Sverige rödlistad som hotad (EN), vilket innebär att arten löper mycket stor risk att dö ut, och ett åtgärdsprogram har upprättats.

\section{Modell och underlagsdata}

Vi använde programmet RAMAS GIS för sårbarhetsanalyserna. Vi utgick från beståndsdata ba- serade på inventeringar under ett antal år hos de bägge arterna på Öland. Den sydliga kärrsnäppan inventerades heltäckande 1988, 1998 och 2008, och stickprovsinventeringar på $20 \%$ av den lämpliga häckningsarealen genomfördes 2003-2008 (Tabell 1). Ängshöken inventerades heltäckande under 2004-2008 (Tabell 2). Från tidsserierna beräknades populationstillväxten mellan intilliggande år. Från dessa värden beräknades i sin tur medelvärde och standardavvikelse, vilka $\mathrm{i}$ simuleringsmodellen motsvaras av populationernas tillväxttakt och omgivningens slumpmässiga variation (t.ex. i klimatiska faktorer eller predationstryck mellan olika år). Som startvärde för simuleringarna använde vi populationsstorleken för det senaste året i arternas respektive inventeringsserier. I dagsläget saknar vi kännedom om hur en eventuell inomartskonkurrens påverkar populationstillväxten. Därför använde vi en modell med exponentiell populationstillväxt och ett s.k. takvärde, d.v.s. en högsta tillåten populationsstorlek. Eftersom små populationer även påverkas av slumpmässiga faktorer i häckningsframgång och överlevnad tog vi med detta i modellen. Vi genomförde s.k. känslighetsanalyser för att se vilka av modellens delar som har störst påverkan på resultatet. I dessa ökade respektive minskade vi modellens ingående delar (populationstillväxt, omgivningens slumpmässiga variation, populationernas start- respektive takvärde) med 10 och $20 \%$.

Förutom dessa grundsimuleringar var det också möjligt att ta med ett par av de hotfaktorer som omnämns i åtgärdsprogrammen. För den sydliga kärrsnäppan gäller detta hur bopredation påverkar den framtida överlevnaden. För ängshökens del gäller det hur den framtida överlevnaden påverkas om de tre häckningsmiljöerna betraktas som en enda sammanhållen population eller som separata delpopulationer, samt hur en spridning till odlingsmarker där häckningsresultatet är sämre, påverkar populationstillväxten.

\section{Resultat}

Utdöenderisken inom de närmaste 100 åren är för sydlig kärrsnäppa $100 \%$, med en mediantid till utdöende på 24 år (Figur 1, Tabell 3). I Figur 1 finns möjlighet att avläsa utdöenderisken även för kortare tidsperioder än 100 år, t.ex. är utdöenderisken under de närmaste 30 åren cirka $70 \%$. Känslighetsanalysen visade att populationstillväxten är viktigast för modellens utfall, medan övriga delar inte påverkar resultatet nämnvärt (Tabell 3). Enligt den 
svenska rödlistan motsvarar simuleringsresultatet för det öländska beståndet en placering i kategorin hotad (EN), vilket innebär att beståndet löper mer än $20 \%$ risk att dö ut inom de närmaste 20 åren. Då bopredation tas med i modellen sjunker överlevnaden ytterligare (Figur 1).

I ängshökens fall är utdöenderisken inom de närmaste 100 åren $70 \%$, med en mediantid till utdöende på 63 år (Figur 2, Tabell 4). Känslighetsanalysen visade att populationstillväxten, och delvis omgivningens slumpmässiga variation, påverkar modellens utfall (Tabell 4). Enligt rödlistan motsvarar simuleringsresultatet för det öländska beståndet en placering i kategorin sårbar (VU), vilket innebär att arten löper mer än 10\% risk att dö ut inom de närmaste 100 åren. Då vi tog med ängshökens tre häckningsmiljöer som separata delpopulationer i modellen, ökade överlevnaden. Överlevnaden ökade mest då vi inte tog med spridning till odlingsmark från de andra två miljöerna (Figur 2, Tabell 5).

\section{Diskussion}

Simuleringsresultaten understryker den allvarliga situationen för de öländska bestånden av sydlig kärrsnäppa och ängshök. Populationstillväxten är den viktigaste faktorn för modellernas utfall hos båda arterna. Denna faktor beror av den årliga häckningsframgången samt unga och äldre fåglarnas överlevnad. Det finns tyvärr inte uppgifter för dessa delars inbördes betydelse för populationstillväxten på Öland, men för den sydliga kärrsnäppan har studier av andra arter inom släktet Calidris visat att det är de äldre fåglarnas överlevnad som är nyckelfaktorn. Den del av populationstillväxten som är möjlig att påverka lokalt på Öland, hos båda arterna, är att skapa goda möjligheter att genomföra lyckade häckningar. I respektive arters åtgärdsprogram diskuteras dessa åtgärder utförligt.

Förutom grundsimuleringarna genomförde vi också simuleringar med några av de faktorer som omnämnts som hot i åtgärdsprogrammen. Hos den sydliga kärrsnäppan gällde detta betydelsen av bopredation för beståndets tillväxt. Simuleringsresultaten visade på en ökning av utdöenderisken då denna togs med i modellen (Figur 1). För närvarande pågår en kartläggning av bopredationens påverkan på häckningsframgången hos vadare på Öland.
Resultaten från dessa studier visar på att bopredation främst sker nattetid, av däggdjur. Att försöka minska bopredationen hos den sydliga kärrsnäppan blir därför en av åtgärderna i bevarandearbetet på Öland.

I ängshökens fall undersökte vi betydelsen av att det finns tre olika häckningsmiljöer, och att en spridning vissa år sker till odlingsmarker där häckningsframgången är lägre. Utdöenderisken minskade tydligt då detta scenario simulerades, även då en spridning förkom till odlingsmarker från de två andra häckningsmiljöerna (Figur 2). En förklaring till detta resultat är att delpopulationer i olika häckningsmiljöer kan påverkas olika av klimatfaktorer och predation, både under och mellan skilda år. Om man istället tänker sig ett bestånd som bara förekommer i en häckningsmiljö kommer vissa år att vara mycket goda för häckningsframgången, medan andra är sämre. När ett bestånd består av ett mindre antal par finns risken att extremt dåliga år påverkar populationernas tillväxt mycket negativt, och hos mycket små populationer kan då ett utdöende ske. I modellen fångas dessa olika förutsättningar upp i den faktor som beskriver omgivningens slumpmässiga variation. Våra känslighetsanalyser visade också att denna faktor hade en viss inverkan på resultaten i ängshökens fall. Vidare visar våra simuleringar att det inte är så negativt med en spridning till odlingsmarker, där häckningsframgången är lägre. Om man istället skyddar ett tillräckligt stort område runt boplatserna i odlingsmarker, eller skjuter på skörden tills häckningen är klar, kan häckningsframgången ökas. Försök som genomförts har visat att ett område på $25 \times 25$ meter runt en boplats kan vara tillräckligt för att häckningen inte ska avbrytas. Detta innebär att en riktad skötsel av häckningar i odlingsmarker, tillsammans med en viss spridning mellan häckningsmiljöerna, ökar möjligheterna för artens överlevnad på Öland. Eftersom bestånden av ängshök i länderna söder om Östersjön inte minskat, kan även en invandring av fåglar från dessa områden öka överlevnaden för det svenska beståndet.

Sårbarhetsanalysen kan förbättras genom att samla in data på häckningsframgång och överlevnad. Modeller där olika åldersklasser ingår kan då utvecklas, och förutsägelserna för arternas framtidsutsikter på Öland kan därmed göras säkrare. 